found excepting inside the shells of species of Helix, the animal of which it had previously devoured. R. MCLACHLAN Lewisham, June 27

Your conespondent, R. S. Newall, is upon the wrong tack, I think. His glow'worm was probably eating the snail, and not vice versố.

In Kirby and Spence's "Entomology" I read: "Snails give sustenance to Di:zats favescens, a beetle, and its singular apterous female in the larva state, as well as to the larvas of glow" worms." Is it not probable that the same food suits the imago state of the insect?

I have often found glow-worms in snail sheils, and have al ways considered slugs and snails to be the natural food of the Lamipyris noctilace.

Bishopsteignton, Devon

R. GREENWOOD PENNY

\section{Frogs and Glow-flies}

Mr. Newall may be, perhaps, interested with the following extract frow Darwin's "Botanic Garden," Canto iv. p. I49, note :-

"In Jamaica, in some seasons of the year, the fire-flies are seen in the evenings in great abundance. When they settle on the ground, the bull-frog greedily devours them; which seems to have given origin to a curious, though cruel method of destroying these animals; if red-hot pieces of charcoal be thrown towards thein in the dusk of the evening, they leap at them, and, hastily swallowing them, are burnt to death."

I was toid a few days ago of a cat which used to search for and eat glow-worms. It was suggested that she took thein for lights. GEORGE HENSLOW

\section{Intellect in Brutes}

THE following instance of sagacity in a cat has just been re. lated to me by a friend who knew both the cat and its owner well. The Iatier, who lived at Ragusa Vecchia, in Dalmatia, was too poor to be able to provide fucd for the cat; the animal was therefore obliged to cater for himself, and was well linown as a thief in the neighbourhood. One day one of the children was being sent off to school without any breakfast; the cat, hearing him sobbing for hunger, immediately went off, and returned with a piece of breat he had stolen from a baker hard by, and brought it to the child. The same thing happened another day, and he came back, dragsing along a piece of meat bigger than himself. On crossing the threshold a bit of bone caught in a bole, so puss miawed till some one came to his help. This same cat, who was constantly catching birds on the roof, slept. with some pet birds in a cage without attempting to touch them.

Ragusa, Austria, June is

MARgaret EvaNS

I SEND you the following instance of intelligence in dogs :Last summer, when on a visit at the château of my son-in-law, M. Richart Waddington, Deputé, near Rouen, I had taken a walk in the grounds, accompanied by some of the family, and two favourte $\log s$, named respectively Minos and Rhadaman. thus, followed the party, as usual, throughout the stroll. When nearing the house, on the return, my young grand-daughter rematke that Minos had lost his collar. The party came to a 32alk, clebating whether it was worth while to go back on a search. ing exvedition, for the pleasure gronds are somewhat exten. sive, and the cogs had been rambling away from the paths among long yrass. Both Minos and Rhadamanthus evidently seemed 10 listen to tine ciebate. It was clecided to make the searcls at a ventme, anc, without saying a word to the dogs, the party commenced to retrace their steps. As a rule, these two dozs are inseparable; wherever the one goes, the other goes, and invariably the two follow any members of the family when strolling about the place. At this juncture, however, Rhadamantbus, not having lost a collar, and having no special interest in the proposed search, went on her solitary way home to the stables ; but Minos kept with the party, walking on the gravel path-and this for some distance-when suddenly he took to the meadow, commenced ruming, and presently he was observed to stop and remain fixed with his head pointed downwards, partly buried in the tall grass. Naturally he was followed. The point of his nose was in contact with the collar! Could any child of man, under similar circumstances, have displayed more thoughtful sagacity than did each of the above dogs on the above occasion? The one thought she was not wanted, and having had enough play, wisely went home, whilst the other, thinking that his presence was requisite, wisely returned with the searching party.

When in Bute, some years ago, I heard from a gentleman, perfectly trustworthy, that a large Newfoundland dog, belonging to a friend of his, was observed one night by its ownei lying concealed under his bed-a strange circumstance, because the dog was forbidden to enter the house at night. The owner, being struck by this singular occurrence, resolved not to disturb the creature, and, getting into bed, kept himself awake to watch events. It was not long before a sound was heard in the pas. sage, a faint light was seen through the key-hole, the door opened, and instantly the dog flew from under the bed, and, springing forward, brought a man to the ground, the gentleman's own servant, who, accompanied by another fellow, was there for the purpose of robbery.

Vicarage, Monkwearmouth

Chas, POPHAM Miles

HAviNG read Mr. Peach's letter on "Intellect in Brutes," as shown by the sagacity he witnessed in his dog, I have been asked to send a similar anecdote, which I have often told to friends. Many years ago my husband had his portrait taken by T. Phillips, sen., R.A., and subsequently went to India, leaving the portrait in London to be finished and framed. When it was sent home about two years after it was taken, it was placed on the floor against the sofa, preparatory to being hung on the wall. We had then a very handsome large black and tan setter, which was a great pet in the house. As soon as the dog came into the room he recognised his master, though he had not seen him for two years, and went up to the picture and licked the face. When this anecdote was told to Phillips, he said it was the highest compliment that had ever been paid to him.

SOME years ago a fine atts exhibition was held at Derby. A portrait of a Derby artist, Wright, was thus sigualised: "The artist's pet dog distinguished this, from a lot of pictures upon the floor of the studio, by licling the face of the portrait."

Derby

HENRY CLARK

\section{Butterfly Swarms}

Wrot reference to the swarms of butterflies referred to by $M$. Forel, in NATURE, vol, xx. p. 197, it may be interesting to mention that Vanessa cardui is this year very common in the south of England. This butterfy is known to all English lepicopterists to be "periodical"-in some seasons it occur's in great numbers, in others-perhaps for several years in succession -not one specimen is to be seen.

Last season (I878) I saw no specimens, nor dià $I$ bear of any about here. It seems, therefore-in such a baci season for insects as the present-impossible to consider the abundance of the species in England to be the result of "local fecundity." Whence, therefore, come these specimens? and is the periodical abundance of the species in Britain due to local causes or migration?

4, East Street, Lewes, July $x$

J. H. A. JENNER

\section{THE KILBURN SHOW}

$T T$ is difficult to estinate the disadvantages with which the Agricultural Exhibition at Kilburn has had to contend. So large a show must always be somewhat unwieldy, however skilfully planned, but the melancholy wet season has enormously increased the difficulties of arrangement, and we may add that tairly to study the implements and miscellaneous exhibits was quite impossible up to the time of otir going to press. A few jottings set down at random concerning such instruments, operations, and specimens as drew our attention while in the yard on Monday must suffice on the present occasion. Visitors were supposed to view the exhibits from the avenues between the long rows of sheds; but these avenues, once grass, were transformed into roads of mud, in every condition of matter between the solid and liquid states. There were no paths across the sheds, and as most of the implements and other exhibits were not so arranged as to be approachable on more than one side, the difficulty of examining objects of interest was frequently insurmountable. 
Perhaps the comparative loan collection of farm implements is the most noticeable feature of the whole show. The paucity of labels and the filthy condition of the ground notwithstanding, the rollers, ploughs, harrows, drills, threshing, winnowing, and reaping machines, are full of interest. Of the actual specimens shown, but few, if any, date back further than the last century, while the majority belong to the furst half of the present. The reapers, including Beli's reaper of 1826 , form an instructive series.

When, about the year 1850 , steam was becoming more generally used for agricultural operations, an immense impetus was giver to the improvement of farm machinery. Richard Trevithich's portable engine, made at Hayle Foundry, in $181 \mathrm{I}$, and put upon Sir C. Hawkins's farm at Trevithen for working a threshing machine, is an historical agricuitural relic far too curious to be allowed to return, after the Kilburn Show is closed, to its prosaic duties in Cornwall. It should be secured for the Patent Museum at South Kensington. It must be regarded as inaugurating the practical use of steam on the farm. The later steps in the progress of steam cultivation may be studied in this loan collection and in the modern implement sheds with tolerable completeness.

Before leaving the subject of the loans exhibited at Kilburn, we may direct our readers to a case exhibited by the Secretary of State for India. It is to be found close to the house in which the plans for farm-buildings are arranged, and in a line with one of the historical implement sheds. The case in question contains specimens of wheat from our Indian Empire, and is accompanied by a map, some remarks on the quality of the wheats, and some statistics. From the latter we learn that India produces 40 million quarters of wheat, of which but $I \cdot 3$ millions were exported in 1877 ; that the demand for wheat of the whole world is at the most but 25 million quarters; and that the United Kingdom requires an average import of II inilion quarters, in addition to her home production of the same quantity. Had chemical analyses of some of these samples of Indian wheat, together with their mill-products, been added to this exhibit, it would have been still more instructive.

In the same shed with the Indian wheats there are shown a series of seventeen cases illustrative of the composition and mutrition of the human body. These are lent by the South Kensington Museum and from what is known as the "Circulating Food Collection." It constitutes a small replica of the most characteristic parts of the Food Collection at Bethnal Green, and like the latter, has been arranged and fully described by Prof. Church. It supplies in an exact yet popular form an immense amount of information concerning the elements and compounds of the human body and of food; and concerning the amount and nature of a day's ration, the equivalents of foods, the analysis and adulteration of alimentary products, the qualities and testing of waters. It has been lent to several provincial exbibitions already, and forms an admirable instrument of popular instruction.

Turning to another department of the show we notice, amongst the raw materials used in the manufacture of manure, some specimens of native phosphates which claim our attention. The search for anything that can be made into superphosphate has certainly been most exhausting. As one supply fails a new one is discovered. The Canadian apatites shown at Kilburn are very fine. Some hexagonal prisms and pure blue crystalline masses are quite museum specimens. Some samples of what are called Russian coprolites are exhibited on Stand 6I5. They are large and have a well-marked radiate structure, closely resembling that often seen in iron pyrites.

We do not recollect ever having before seen the seed of the locust bean, Ceratonia siliqua, prepared for food by simple splitting, as shown in a fine sample (No. II,08I) on Stand 595. Some specimens of selected or pedigree wheat, on Stand 629, are noticeable.

The artificial drying of hay and some other crops is likely to be more extensively employed before long. $\mathrm{Mr}$. W. A. Gibbs, the inventor, shows some improved forms of his implement for this purpose. They effectually get rid of the excess of moisture in the materials submitted to the process of artificial desiccation without stewing them. One machine can dry out 35 per cent. of water from hay at the rate of twenty loads a day. Another instrument, of which a model is also shown, is specially adapted for drying tea, coffee, manures, hops, and fruit.

It is impossible to do justice, in a single set of brief jottings like the present, to any of the subjects we have handled. We can but direct attention to some of the characteristic features of the stands, and to two or three out of the thousands of specimens shown. We should like to have dwelt upon numbers of inventions to which we have no space to allude; but we cannot refrain from noticing the exquisitely ingenious application of hydraulic pressure to the automatic opening, and, what is more curious, the automatic closing, of entrance gates by the pressure of the passing vehicle. The interval between the opening and the spontaneous closing of these gates can moreover be regulated to a nicety by a previous adjustment. A large working model of this invention will be found at Stand $14 \mathrm{i}$, the patentee being W. Walton, of Runiley, Manchester. We must also note a charming chromolithographic diagram of the colours acquired by the metal in tempering steel from the pale straw proper to "scrapers for brass" through shades of orange, red, and purple to the deep blue of "springs." This was issued as a supplement to the Ironmonger of April 5, 1879 , and is shown at Kilburn on the stand appropriated to that paper.

We have not space to speak of the many admirable features of the showyard, nor even of the delightful little train of steam tramcars working on rails of less than two feet gange. But we may return to the subject of the Kilburn Show next week.

\section{MAFOR PINTO'S AFRICAN FOURNEY}

M AJOR SERPA PINTO has been lecturing in Lisbon I to a distinguished audience on his journey across Africa from Benguella to Durban. He apologises for the disjointed character of his lecture, for which he had no time to prepare, and which, therefore, cannot be taken as anything like a complete account of the results of his journey. There is some likelihood of his soon being in London, and probably then he may give us a more systematic: account of what he has been able to gather in the interesting region through which he passed. A good deal has been said of the large natural history and other collections he has made, and if these be such as they have been represented, science will certainly be much indebted to the gallant Major, who has tried to revive the glories of the old days when Portugal was in the front rank of exploring nations. A good many difficulties were met with at the beginning as usual, and Major Pinto deemed it advisable to separate himself from his companions Ivens and Capello, who took a more northern route, and as they had various scientific instruments with them, including such as were suitable for observations in terrestrial magnetism, possibly they may have some important contributions to make to science.

It is difficult to make much out of Major Pinto's rambling talk, which often reminds us of the vague and wonderful stories told by the simple travellers of old. He certainly seems to have made important rectifications in the hydrography of South-West Africa, especially of that flat table-land about $12^{\circ} \mathrm{S}$, and $18^{\circ} \mathrm{E}$., where within a few paces one can drink of the water of the sources of the Zambesi, Coanza, and Cubango, and where it can easily 